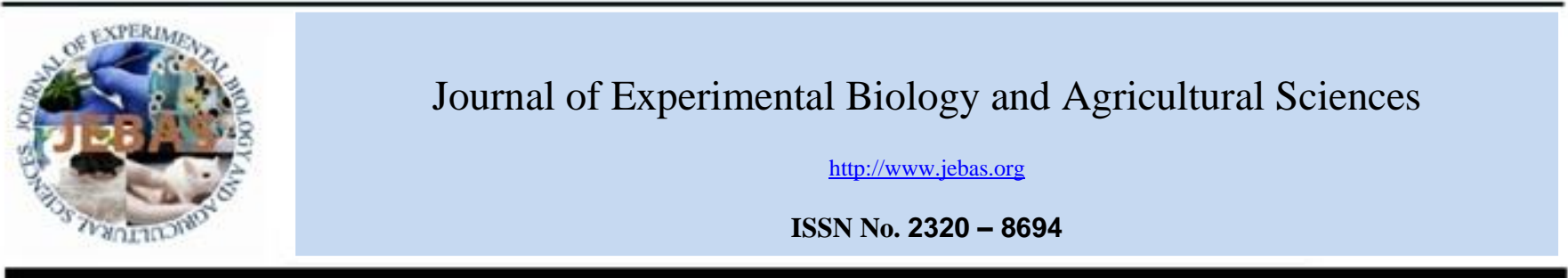

\title{
PHENOTYPIC AND GENOTYPIC CHARACTERIZATION OF FIVE ANTIMICROBIAL RESISTANCE GENES ASSOCIATED WITH Klebsiella pneumoniae ISOLATED FROM BURN INFECTION PATIENTS
}

\author{
Mohsin Razzaq Azeez ${ }^{1}$, Ahmed Abduljabbar Jaloob Aljanaby ${ }^{2 *}$ (D), Ilkay Çorak Öcal ${ }^{3}$ \\ ${ }^{1,3}$ University of Karatekin, Faculty of Science, Department of Biology, 18200, Çankiri, Turkey \\ ${ }^{2}$ University of Kufa, Faculty of Science, Department of Biology, Iraq
}

Received - May 16, 2021; Revision - June 07, 2021; Accepted - June 21, 2021

Available Online - June 25, 2021

DOI: http://dx.doi.org/10.18006/2021.9(3).378.387

\section{KEYWORDS \\ Klebsiella pneumonia \\ Burn infection \\ Antibiotic resistance \\ Beta lactamase genes \\ Iraq}

\section{* Corresponding author}

E-mail: ahmedaj.aljanabi@uokufa.edu.iq (Ahmed Abduljabbar Jaloob Aljanaby)

Peer review under responsibility of Journal of Experimental Biology and Agricultural Sciences.

Production and Hosting by Horizon Publisher India [HPI] (http://www.horizonpublisherindia.in/).

All rights reserved.

\begin{abstract}
The current study was carried out for the phenotypic and genotypic characterization of five antimicrobial resistance-associated genes in Klebsiella pneumoniae isolated from burn infection patients. Total one hundred three (103) bacterial samples (strains) were isolated from the 103 burn infection patients admitted at Middle Euphrates Burns Center of AL-Kufa City Iraq. Out of total isolated bacterial samples (103), there were 31 isolates (30\%) identified as Pseudomonas sp., 23 isolates (22.3\%) as K. pneumonia, 22 isolates as Staphylococcus sps. (21.4\%), 11 isolates as E. coli (10.6\%), 8 isolates as Acinetobacter sps. (7.8\%), 5 isolates as Enterobacter sps. (4.9\%), while the lowest prevalence (3 isolates) was reported for the Proteus spp. (3\%). The antimicrobial sensitivity test indicated that all isolated K. pneumoniae have resistant (100\%) against standard antibiotic Amoxicillin. While Imipenem is the only antibiotic that can inhibit the growth of all 23 isolates. Further, according to the phenotypic detection method, there were 14 isolates $(61 \%)$ capable of production of extended spectrum beta lactamase (ESBL). Genotypic method to detect the presence of five antibiotic resistance genes by polymerase chain reaction proved that 13 isolates $(56.5 \%)$ were Tem gene, 18 isolates $(78.2 \%)$ were positive for $S h v$ gene, 8 isolates $(34.7 \%)$ were positive Ctxm gene, three isolates (13\%) were positive for $O x a$ gene and 10 isolates (43.7\%) positive for $A m p C$ gene. Results of the study can be concluded that $K$. pneumoniae is the second causative agent that causes burn infection and has higher antibiotics resistance. Extended spectrum beta lactamase of K. pneumoniae was higher prevalence in burn infection and harbored many beta lactamase genes.
\end{abstract}

All the articles published by Journal of Experimental Biology and Agricultural Sciences are licensed under a Creative Commons Attribution-NonCommercial 4.0 International License Based on a work at www.jebas.org.

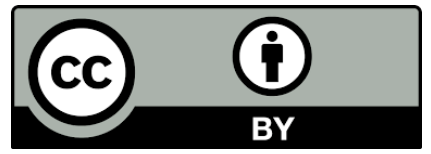




\section{Introduction}

Hospital-acquired infections, such as burns, skin infections, and eventually reproductive system infections, urinary tract infections, blood, gastrointestinal soft tissue infections, and respiratory tract infections, are the leading causes of hospitalization (Rup et al., 2021). Burn injuries are of public health importance in both developed and developing countries. It is associated with several complications such as functional disability, severe scarring, and contractures of the affected body part (Jeschke et al., 2020). Burn injuries affect the skin to a large extent (Aljanaby et al., 2018; Hansen et al., 2019; Neog et al., 2021).

Infection is the most common complication of burn patients after admission, leading to higher morbidity and mortality (NavonVenezia et al., 2017). The presence of multidrug-resistant pathogenic bacteria increases the impact of hospital-acquired infections (El-Mokhtar et al., 2021). Among the most common bacteria associated with burn infection, K. pneumoniae is one of the most widespread bacteria and the second pathogen after Pseudomonas (Sharahi et al., 2020). This might be due to the antibiotic resistance in bacteria, these resistance bacteria have antibiotics resistance plasmid and have high resistance against various antibiotics such as ampicillin and carbenicillin (Yap et al., 2013). Multidrug-resistant bacteria and extended spectrum beta lactamase with high prevalence distributions in both hospitals and the general population growth in K. pneumoniae and other GramNegative bacteria (Legese et al., 2017). Almost 390 distinct forms of ESBLs, including bla genes such as tem and ctxm, have been worldwide recognized (Barguigua et al., 2011). Furthermore, multidrug resistance and ESBL develop in $K$. pneumoniae when antimicrobials such as beta-lactams, cephalosporins, aminoglycosides, and others are used, resulting in a loss of care in hospitals and ambulatory patients (Tang et al., 2017). The purpose of this study was to evaluate the incidence of $K$. pneumoniae as a causal agent in burn infections in hospitalized patients and also establish their antibiotic resistance patterns and associated gene using phenotypic and genotypic approaches.

\section{Materials and Methods}

\subsection{Study design and numbers of burn swabs}

This is a cross-sectional descriptive study carried out at the laboratory of Kufa University, Faculty of science, department of microbiology, Iraq during the period between August to December 2020. A total of 103 burn swabs (male and female) were collected from hospitalized patients at Middle Euphrates Burn Center in ALKufa City.

\subsection{Ethical considerations}

Before starting the study, the written consent and ethical approval were taken from all the selected 103 patients. Every swab sample was taken by an experienced physician or a healthcare team member from the hospital, and the collected swab samples were taken to the microbiology laboratory, University of Kufa, Iraq for further processing (Figure 1).

\subsection{Culturing of Burns swabs and bacterial identification}

The collected swab samples were stroked on the blood agar and brain heart infusion broth for 24 hours at $37^{\circ} \mathrm{C}$ for suitable bacterial growth. Bacterial isolation has been determined by blood hemolysis on blood agar, gram stain, oxidase test, catalase test, imvic test, motility test, coagulase test, and growth on MacConkey agar (MacFaddin, 2000; Aljanaby, 2013; Aljanaby, 2018).
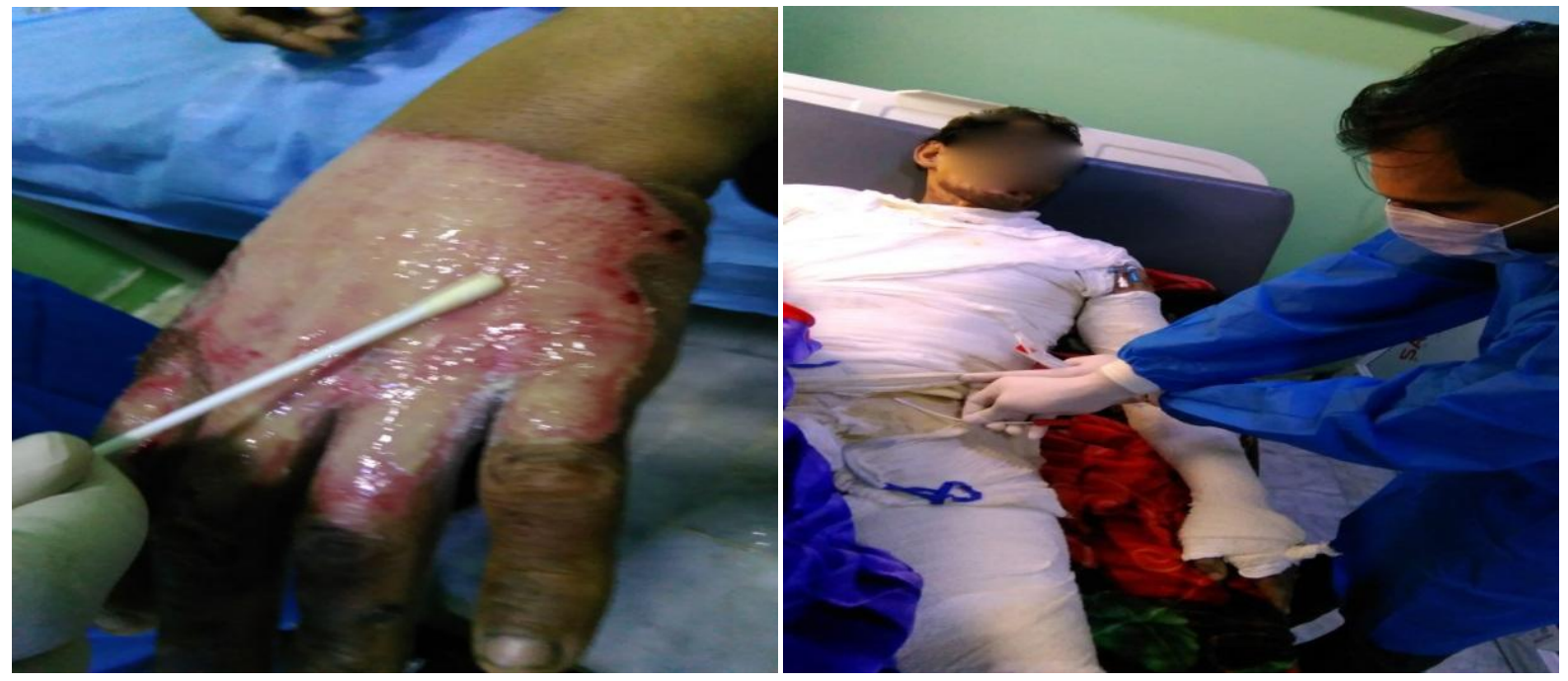

Figure1 Burn swab samples collected from the patients admitted to the Middle Euphrates Burn Center of AL-Kufa City.

Journal of Experimental Biology and Agricultural Sciences http://www.jebas.org 


\subsection{Antibacterial susceptibility test}

Isolated bacterial strains were subject to antibiotic sensitivity or resistance tests, for this eleven different antibiotic discs were utilized: the majority of them being OxoidTM discs made in the United States. Resistance to antibiotic assays was evaluated using disc diffusion and the Kirby-Bauer method on Mueller Hinton agar (Oxoid ${ }^{\mathrm{TM}}$, USA, PO5007A) (Bauer et al., 1966). For estimation of antibiotic sensitivity or resistance, the used antibacterial discs have Penicillin G $50 \mu \mathrm{g}$ (CT0004B), Cefotetan 30 $\mu \mathrm{g}$ (CT0268B), Gentamicin Sulfate $15 \mu \mathrm{g}$ (CT0300B), Ceftazidime Sulfate $15 \mu \mathrm{g}$ (CT0407B), Levofloxacin Sulfate $15 \mu \mathrm{g}$ (CT0311B), Ciprofloxacin Sulfate $5 \mu \mathrm{g}$ (CT0436B), Gentamicin Sulfate $15 \mu \mathrm{g}$ (CT0317B), Ceftazidime Sulfate $15 \mu \mathrm{g}$ (CT0432B), Levofloxacin Sulfate $15 \mu \mathrm{g}$ (CT0326B), Gentamicin Sulphate $15 \mu \mathrm{g}$ (CT0311B), CeftazidimeSulphate $15 \mu \mathrm{g}$ (CT (CT0056B) antibacterial solution was used in the above-mentioned concentration. To find out the diameters of inhibition zones, one unassisted eye measurement is sufficient. Subsequently, clinical and laboratory standards of CLSI guidelines 2020 were used to find out the exact diameter of inhibition zones. A bacterial isolate that was resistant to at least three different antibiotic classes is considered an MDR strain, If any bacterial isolate was resistant to all antimicrobial classes except two or three were considered as extensive drug resistance(XDR) (Leber, 2020).

\subsection{Phenotypic detection method}

Double disc synergy test (MDDST) as described by Kaur et al. (2013) was used to distinguish E. coli expressing extended spectrum beta lactamase (as described above) that phenotypically express EBSBA from regular $E$. coli (as described above). Every step in streaking and plating bacterial isolates (turbidity was adjusted to a $1 \mathrm{McFarland}$ tube and 0.5 Himedia India) was carried out using a sterile swab (Himedia, India) on Mueller Hinton agar (OxoidTM, USA). Then, an AMC antibiotic disc $(30 \mu \mathrm{g})$ was inserted in the middle of the agar plate, and the other aforementioned medications, such as CRO, CTX, and CAZ antibiotics were dispersed around the AMC disc (15 mm from center to center). Every plate was incubated at $37{ }^{\circ} \mathrm{C}$ in a microaerobic atmosphere for 24 hours, and then each plate was plunged into an incubator at $37^{\circ} \mathrm{C}$ temperatures for the next 24 hours. An increase in the inhibitory zone around the AMC disc was considered a good outcome for the extended spectrum beta-lactamase (Majeed \& Aljanaby, 2019).

\subsection{Extraction of total DNA}

From the isolated bacterial strain DNA extraction was carried out as per the method described by Aljanaby \& Alhasnawi (2017a). For this, aged water with five distinctively clean bacterial colonies was added to 500 microliters of distilled water, and the resulting solution was heated on a water bath for 30 minutes. This was followed by centrifugation @ 7500 rpm for 20 minutes and the supernatant was collected.

\subsection{PCR and thermal cycling conditions}

Five different primer sequences for the selected five genes which were employed in the present investigation and thermal cycling conditions are presented in tables 1 and 2 . The PCR product samples were examined using gel electrophoresis with $2 \%$ agarose, to produce five $\mu 1$ aliquots. The electrophoresis was done using an electric current of 80 volts for 90 minutes and molecular size DNA nucleic acid marker (1000bp ladder, 50 to $1500 \mathrm{bp}$ ). Ethidium bromide was used as a staining agent $(2 \mathrm{mg} / \mathrm{ml})$, and observation was taken under ultraviolet light.

\subsection{Statistical analysis}

The percentages have been used in this study to compare all data and antibacterial resistance (Aljanaby, 2018; Tong et al., 2021).

Table1 Primers used in this study

\begin{tabular}{|c|c|c|c|}
\hline Gene & Oligo Sequence $\left(3^{\prime} \rightarrow 5^{\prime}\right)$ & Product Size (bp) & Reference \\
\hline$S H V$ & $\begin{array}{l}\text { F- GGCCGCGTAGGCATGATAGA } \\
\text { R- CCCGGCGATTTGCTGATTTC }\end{array}$ & 714 & \\
\hline TEM & $\begin{array}{l}\text { F- CAGCGGTAAGATCCTTGAGA } \\
\text { R- ACTCCCCGTCGTGTAGATAA }\end{array}$ & 643 & Ensor et al. (2009) \\
\hline$C T X-M$ & $\begin{array}{l}\text { F-AACCGTCACGCTGTTGTTAG } \\
\text { R-TTGAGGCGTGGTGAAGTAAG }\end{array}$ & 766 & \\
\hline$O X A$ & $\begin{array}{c}\text { F-ATATCTCACTGTTGCATCTCC } \\
\text { R- AAACCCTTCAAACCATCC }\end{array}$ & 618 & Tuwaij et al. (2020) \\
\hline$A M P C$ & $\begin{array}{c}\text { F-ATCAAAACTGGCAGCCG } \\
\text { R-GAGCCCGTTTTATGCACCCA }\end{array}$ & 550 & Paterson et al. (2003) \\
\hline
\end{tabular}

Journal of Experimental Biology and Agricultural Sciences http://www.jebas.org 
Table 2 Programs of PCR thermo cycling conditions

\begin{tabular}{|c|c|c|c|c|c|c|c|}
\hline \multirow[b]{2}{*}{ Gene } & \multirow{2}{*}{$\begin{array}{c}\text { Initial } \\
\text { Denaturation } \\
\left({ }^{\circ} \mathrm{C} / \text { Time }\right)\end{array}$} & \multicolumn{4}{|c|}{ Cycling condition $\left(\mathrm{C}^{\mathrm{o}}\right.$, Time $)$} & \multirow{2}{*}{$\begin{array}{c}\text { Final } \\
\text { extension } \\
\left({ }^{\circ} \mathrm{C} / \text { Time }\right)\end{array}$} & \multirow[b]{2}{*}{ Reference } \\
\hline & & Denaturation & Annealing & Extension & $\begin{array}{l}\text { Number of } \\
\text { Cycles }\end{array}$ & & \\
\hline TEM & $95^{\circ} \mathrm{C} / 5 \mathrm{~min}$ & $94{ }^{\circ} \mathrm{C} / 30 \mathrm{sec}$ & $52{ }^{\circ} \mathrm{C} / 45 \mathrm{sec}$ & $72{ }^{\circ} \mathrm{C} / 45 \mathrm{sec}$ & 30 & $72{ }^{\circ} \mathrm{C} / 7 \mathrm{~min}$ & \multirow{3}{*}{ Ensor et al. (2009) } \\
\hline$S H V$ & $95^{\circ} \mathrm{C} / 5 \mathrm{~min}$ & $94{ }^{\circ} \mathrm{C} / 30 \mathrm{sec}$ & $55^{\circ} \mathrm{C} / 60 \mathrm{sec}$ & $72{ }^{\circ} \mathrm{C} / 45 \mathrm{sec}$ & 30 & $72{ }^{\circ} \mathrm{C} / 7 \mathrm{~min}$ & \\
\hline $\begin{array}{c}C T X_{-}^{-} \\
M\end{array}$ & $94{ }^{\circ} \mathrm{C} / 5 \mathrm{~min}$ & $94{ }^{\circ} \mathrm{C} / 45 \mathrm{sec}$ & $57{ }^{\circ} \mathrm{C} / 45 \mathrm{sec}$ & $72{ }^{\circ} \mathrm{C} / 45 \mathrm{sec}$ & 30 & $72{ }^{\circ} \mathrm{C} / 7 \mathrm{~min}$ & \\
\hline$A M P C$ & $94{ }^{\circ} \mathrm{C} / 5 \mathrm{~min}$ & $94{ }^{\circ} \mathrm{C} / 45 \mathrm{sec}$ & $60{ }^{\circ} \mathrm{C} / 45 \mathrm{sec}$ & $72^{\circ} \mathrm{C} / 60 \mathrm{sec}$ & 35 & $72{ }^{\circ} \mathrm{C} / 5 \min$ & $\begin{array}{l}\text { Paterson et al. } \\
\text { (2003) }\end{array}$ \\
\hline$O X A$ & $94{ }^{\circ} \mathrm{C} / 5 \mathrm{~min}$ & $94{ }^{\circ} \mathrm{C} / 60 \mathrm{sec}$ & $55^{\circ} \mathrm{C} / 60 \mathrm{sec}$ & $72{ }^{\circ} \mathrm{C} / 60 \mathrm{sec}$ & 30 & $72{ }^{\circ} \mathrm{C} / 10 \mathrm{~min}$ & $\begin{array}{c}\text { Tuwaij et al. } \\
\text { (2020) }\end{array}$ \\
\hline
\end{tabular}

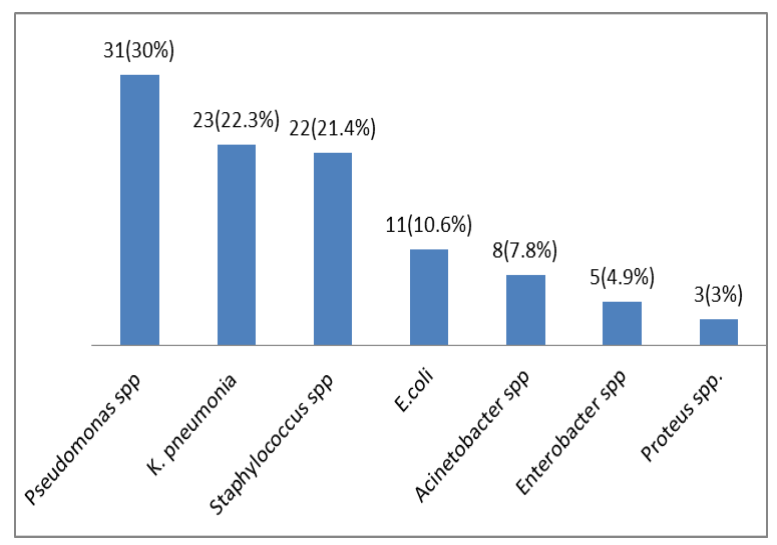

Figure 2 The number and percentage of total bacterial isolates obtained from the patients suffering from the burn infection.

\section{Results}

\subsection{Total bacterial isolates}

Figure 2 showed the numbers and percentages of bacterial isolates isolated from 103 patients (53 male and 50 female) with burn infections. The results of the current study revealed that among the 103 respondents, there were 31 (18 male and 13 female) patients were suffering from the infection of Pseudomonas sps., 23 (12 male and 11 female) were from K. pneumonia followed by 22 (11 male and 11 female) from Staphylococcus spp, and 11 (4 male and 7 female) from E.coli (Figure 3). While there were 8 patients (3 male and 5 female) who were suffering from the Acinetobacter spp. infection, 5 (3 male and 2 female) were from Enterobacter sps., and the lowest prevalence was reported for Proteus sps. with 3 isolates ( 2 male and 1 female).

\subsection{Screening of antibiotics resistance}

The results presented in Table 3 revealed that all $23 \mathrm{~K}$. pneumoniae isolates had complete resistance (100\%) against standard antibiotic Amoxicillin and Ceftriaxone while these isolates had high

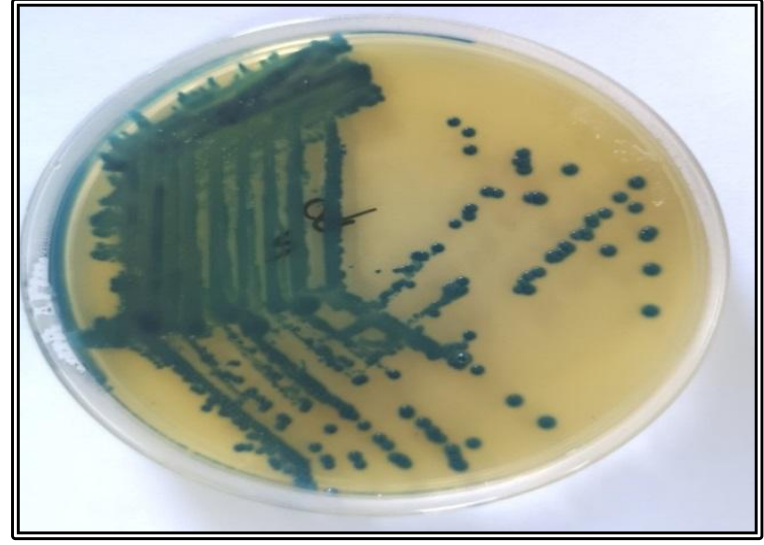

Figure 3 Single metallic green colonies of $K$. pneumoniae onto chrome agar at $37^{\circ} \mathrm{C}$ for $24 \mathrm{~h}$.

resistance $(91.3 \%)$ to Amoxicillin + Clavulanic acid combination. On the other hand, the results of this study demonstrated that $K$. pneumoniae also had resistance to Cefotaxime (73.9\%), Ceftazidime (43.4\%), Tetracycline (69.5\%), Tobramycin (60.9\%), and Ciprofloxacin (47.8\%). While, there was low resistance against Levofloxacin (17.1\%), Gentamicin (13\%), and Amikacin (4.3\%). Among the tested antibiotics, Imipenem was the only antibiotic that inhibited the growth of all 23 isolates.

\subsection{Type of resistance}

Results given in figure 4 suggested that $87 \%$ of K.pneumoniae isolates have multidrug resistance (MDR), while the remaining $13 \%$ have XDR, and no isolates have PDR characteristics (bacterial isolate resistance to all subclasses in all classes of antibiotics).

\subsection{Extended-spectrum beta-lactamase (ESBL) phenotypic test}

This test was carried out according to Double Disc Synergy Test (DDST). The results proved that out of 23 isolates, 14 isolates (61\%) were capable of production of ESBL (Figure 5). 
Table 3 Antibiotics sensitivity of the 23 Klebsiella pneumoniae isolates.

\begin{tabular}{|c|c|c|c|}
\hline Antibiotics & $\begin{array}{c}\text { Sensitive } \\
\mathrm{N}(100 \%)\end{array}$ & $\begin{array}{l}\text { Intimidated } \\
\mathrm{N}(100 \%)\end{array}$ & $\begin{array}{l}\text { Resistance } \\
\text { N }(100 \%)\end{array}$ \\
\hline Amoxicillin $(25 \mu \mathrm{g})$ & $0(0 \%)$ & $0(0 \%)$ & $23(100 \%)$ \\
\hline Amoxiclav $(30 \mu \mathrm{g})$ & $2(8.7 \%)$ & $0(0 \%)$ & $21(91.3 \%)$ \\
\hline Cefotaxime $(30 \mu \mathrm{g})$ & $5(21.7 \%)$ & $1(4.4 \%)$ & $17(73.9 \%)$ \\
\hline Ceftazidime $(30 \mu \mathrm{g})$ & $8(34.8 \%)$ & $5(21.8 \%)$ & $10(43.4 \%)$ \\
\hline Ceftriaxone $(30 \mu \mathrm{g})$ & $0(0 \%)$ & $0(0 \%)$ & $23(100 \%)$ \\
\hline Levofloxacin $(30 \mu \mathrm{g})$ & $13(56.8 \%)$ & $6(26.1 \%)$ & $4(17.1 \%)$ \\
\hline Imipenem $(10 \mu \mathrm{g})$ & $20(87 \%)$ & $3(13 \%)$ & $0(0 \%)$ \\
\hline Tetracycline $(30 \mu \mathrm{g})$ & $7(30.5 \%)$ & $0(0 \%)$ & $16(69.5 \%)$ \\
\hline Ciprofloxacin $(5 \mu \mathrm{g})$ & $7(30.8 \%)$ & $5(21.7 \%)$ & $11(47.8 \%)$ \\
\hline Gentamicin $(15 \mu \mathrm{g})$ & $19(82.7 \%)$ & $1(4.3 \%)$ & $3(13 \%)$ \\
\hline Amikacin $(30 \mu \mathrm{g})$ & $22(95.7 \%)$ & $0(0 \%)$ & $1(4.3 \%)$ \\
\hline Tobramycin $(10 \mu \mathrm{g})$ & $5(21.7 \%)$ & $4(17.4 \%)$ & $14(60.9)$ \\
\hline
\end{tabular}

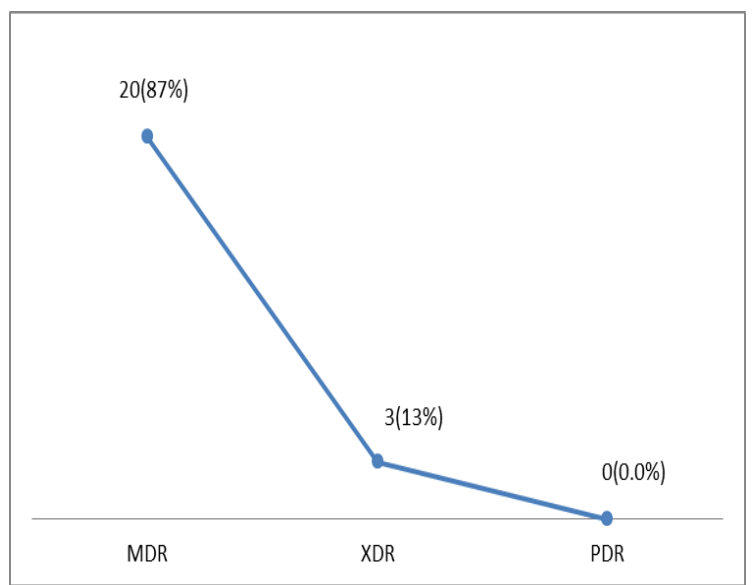

Figure 4 Type of resistance (Numbers and percentages) in 23 isolates of K.pneumoniea

\subsection{Molecular detection of antibiotics resistance associated genes}

All the antibiotic resistance-linked gene findings were given in figure 6. Of the 23 isolates, there were $13(56.5 \%)$ isolates that had tem gene (Figure 7), 18 isolates were found positive for the shv gene (Figure 8), $8(34.7 \%$ ) isolates were harboring the ctxm gene (Figure 9), three (13\%) were positive for oxa gene (Figure 10) while 10 isolates $(43.7 \%$ ) were positive for the $A m p C$ gene (Figure $11)$.

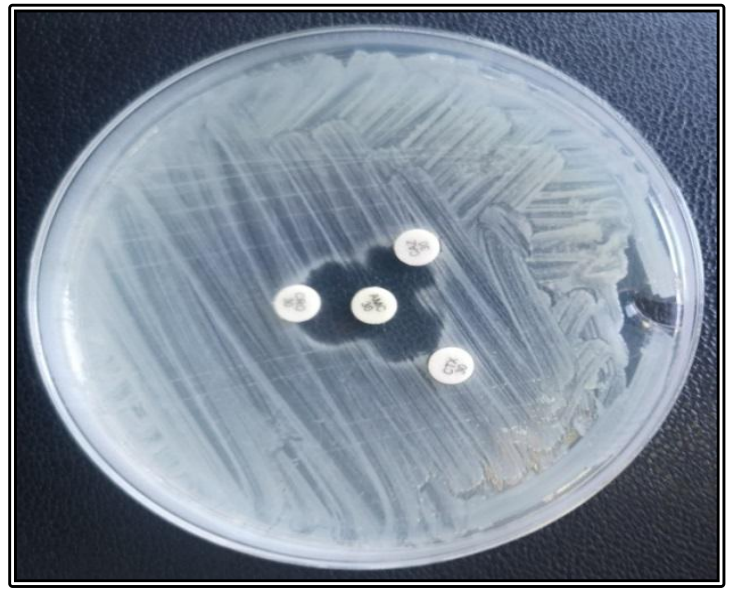

Figure 5 Phenotypic confirmatory test of ESBL for $K$. pneumoniae by Double Disc Synergy Test.

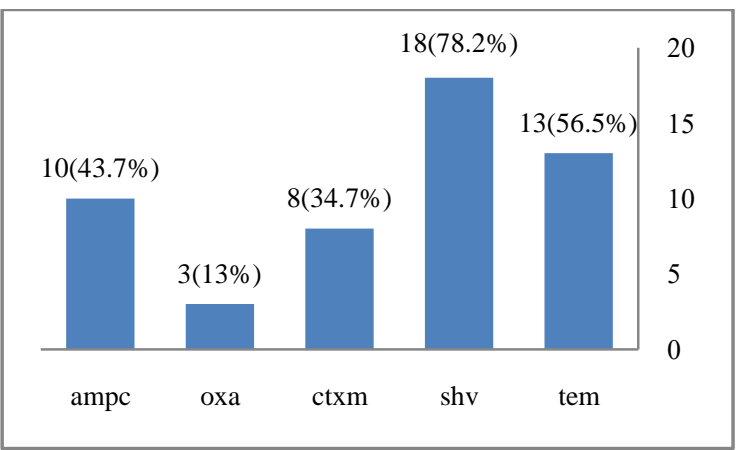

Figure 6 Prevalence of antibiotic resistance genes in $K$. pneumoniae

Journal of Experimental Biology and Agricultural Sciences http://www.jebas.org 


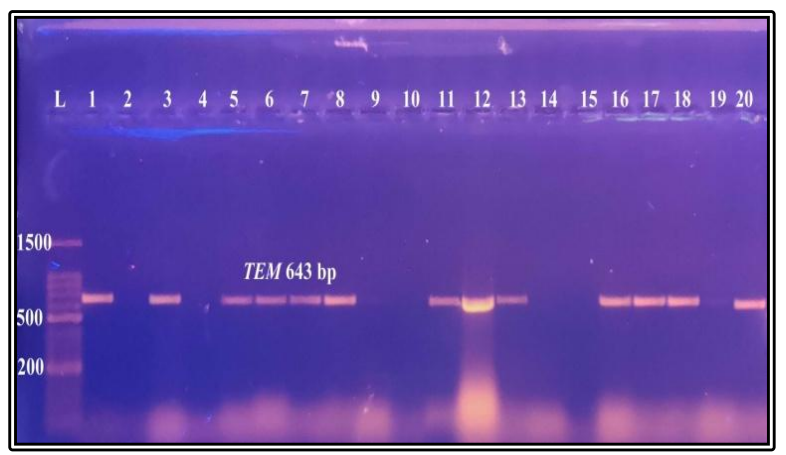

Figure 7 The prevalence of Tem gene in K. pneumoniae amplified by PCR and separated by agarose gel electrophoresis

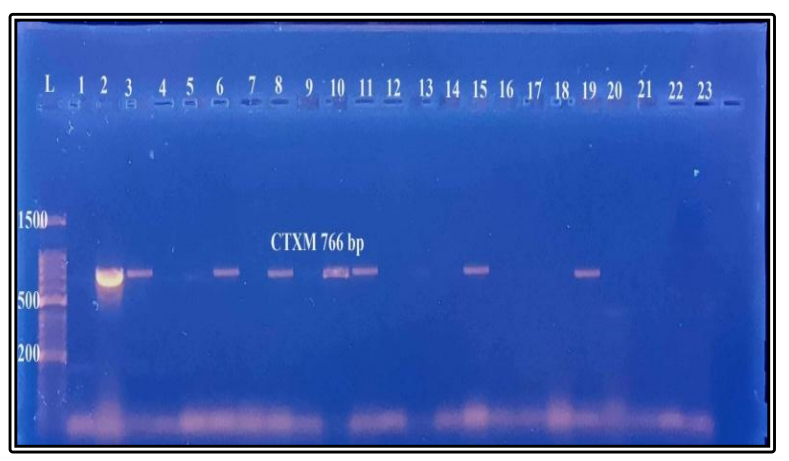

Figure 9 The prevalence of Ctxm gene in K. pneumoniae amplified by PCR and separated by agarose gel electrophoresis

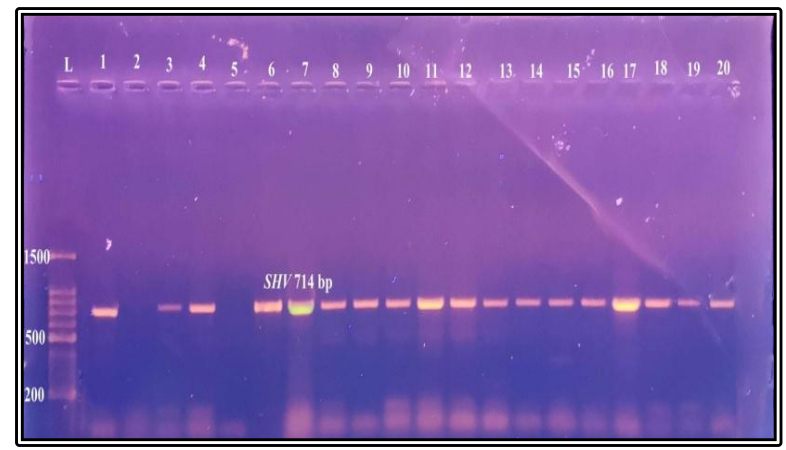

Figure 8 The prevalence of Shv gene in K. pneumoniae amplified by PCR and separated by agarose gel electrophoresis

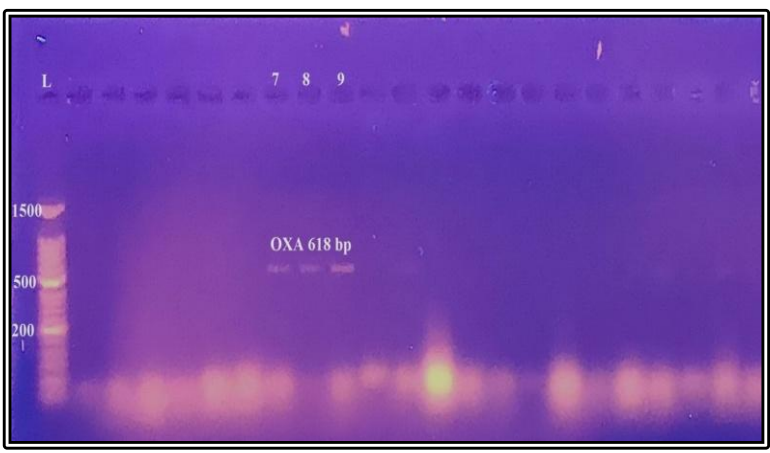

Figure 10 The prevalence of $O x a$ gene in $K$. pneumoniae amplified by PCR and separated by agarose gel electrophoresis

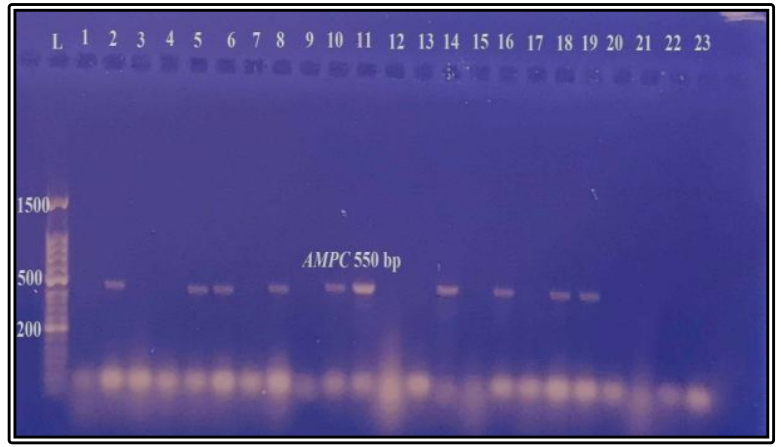

Figure 11 The prevalence of AmpC gene in K. pneumoniae amplified by PCR and separated by agarose gel electrophoresis

\section{Discussion}

Antibiotics are one of the most widely used therapies for the treatment of many kinds of bacterial infections. Antibiotic resistance is a significant clinical issue in the treatment of bacterial infections globally; in the current study, all isolates were evaluated for antibiotic resistance as per the CLSI-recommended antimicrobial drugs (2020). Frequent uses of antibiotics without sensitivity testing are the primary factor that significantly contributes to the development of multidrug resistance, which resulted in the selection and spread of antibiotic resistance in the bacteria under clinical care (Hernando-Amado et al., 2019). The fast development of antibiotic-resistant pathogens disables the effectiveness of the treatments which is developing a dangerous issue for public health (Borges et al., 2016).

In the current study, the results presented in Table 3 revealed that all $23 \mathrm{~K}$. pneumoniae strains have complete resistance against 
standard antibiotic Amoxicillin and Ceftriaxone, while these strains high resistant $(91.3 \%)$ against Amoxicillin + Clavulanic acid, and no resistance was reported against Imipenem. These results are in agreement with the findings of Kandela (2011) those who reported the most striking results that $K$. pneumoniae isolates were resistant to Cefotaxime (80 \%), and highly resistant to Cephalosporin, and moderately resistant to Ceftazidime. Similarly, Lari et al. (2013) reported K. pneumoniae antibiotic resistance against various antibiotics such as Cefotaxime (91\%), Tobramycin $(86 \%)$, Tetracycline $(80 \%)$, Gentamicin $(72 \%)$, Amikacin $(71 \%)$, Amoxicillin/ clavulanic acid (71\%), Chloramphenicol (63\%) and Imipenem (54\%) in Iran.

In other studies, Mariya \& Hatkar (2015) have reported moderate to higher K. pneumoniae antibiotic resistance to Amikacin, Salih et al. (2018) against Nalidixic acid, and Aljanaby \& Alhasnawi (2017b) against Amoxicillin and Amoxicillin with Clavulanic acid combination. Results of the current study are contradictory to the findings of Al Sanjee et al. (2020), those who reported lower $K$. pneumonia resistance against the most commonly used antibiotic drugs such as Amoxicillin (20\%), Cefotaxime (0\%), Ciprofloxacin (70\%), and Gentamycin (40\%), this variation might be due to experimental conditions or absence of the antibiotic resistance plasmid or gene.

There are two types of antibiotic resistance i.e. acquired and natural resistance (Landecker, 2016). Natural resistance refers to the capability of an organism to avoid antibiotic effects by having inherited properties. This kind of resistance was reported in various kinds of gram negative bacteria such as $E$. coli which has natural resistance against Penicillin $G$ due to the absence of specific antibiotic receptors on its surface (Lewies et al., 2019). On the other hand, there is an acquired resistance that is determined as quality alterations in the genetic materials (mutation) of the organism which helps microorganisms to defend themselves against antibiotics (Bengtsson-Palme et al., 2018). Further, horizontal gene transfer is the way in that bacteria acquired their resistant genes from a donor bacterium (Soucy et al., 2015).

Many $K$. pneumoniae strains have antibiotic resistance due to the presence of tem and shv plasmid-encoded class A enzymes (Miryala et al., 2020). Mutations in these tem and $s h v$ genes have resulted in extended spectrum beta lactamase enzymes, which have been well characterized in the Enterobacteriaceae family, especially in K. pneumoniae (Aljanaby \& Alhasnawi, 2017a). The results of the current study revealed the presence of $56.5 \%$ tem (Figure7) and $78.2 \%$ shv gene from the genetic combination of $K$. pneumoniae which helpful in the establishment of antibiotic resistance of this bacteria (Figure 9). In contrast to this, Ahmed et al. (2013) reported only $10 \%$ of the shv gene from the $K$. pneumoniae isolates. Other studies by Izadí et al. (2014) indicated that $43 \%$ of $K$. pneumoniae bacterial isolates were
ESBL's positive outpatient and have tem (87\%), shv (69.64\%) gene while $48.21 \%$ isolates have the presence of both tem and $s h v$ gene. The results of Aljanaby \& Alhasani (2015) showed that the prevalence of $s h v$ and tem gene was $91.66 \%$ and $100 \%$ respectively.

Further, the results of the current study reported that 8 (34.7\%) isolates were positive for the ctxm gene (Figure 9). It has been reported that there has been a clonal expansion of ctxm gene rating K. pneumoniae isolates in Saudi Arabia, Egypt, Iran, Oman, Lebanon, the Gulf Council, Iraq, Kuwait, and Turkey (Zowawi et al., 2014; Yezli et al., 2015). Additionally, in conjunction with ctxm and virulence genes creating multidrug-resistant $K$. pneumoniae, the therapy combinations in this treatment regimen might further exacerbate infections and lower the probability of successful therapy (Derakhshan et al., 2016).

The molecular detection of antibiotics resistance genes revealed that $3(13 \%)$ isolates were positive for the oxa gene (Figure10). This result is contradictory to the findings of Sugumar et al. (2014), and Amirkamali et al. (2017), those who reported the presence of 46 and $37.3 \%$ oxa gene respectively. Further, results presented in figure11 suggested that 10 isolates (43.7\%) were positive for the $A m p C$ gene. This result is similar to Gupta et al. (2012) who reported that $32 \%$ of isolates have the AmpC gene. Class D lactamases are also called oxa-cillinases or oxa-lactamases because they can hydrolyze oxalic acid more efficiently than benzylpenicillin. These enzymes were first discovered in the late 1960s and early 1970s and showed hydrolytic activity against penicillin and oxacillin (King et al., 2016).

\section{Conclusions}

$K$. pneumoniae is a second causative agent that causes burn infection and had a high ability to resistant antibiotics. Further, extended spectrum beta lactamase $K$. pneumoniae was high prevalence in burn infection and harbored many beta lactamase genes.

\section{Conflict of Interest}

This study does not have any conflict of interest

\section{Source of Funding}

There was no fund in this study, fund by authors themselves

\section{Data Availability}

Data presented in this study are available on fair request to the corresponding author. 


\section{References}

Ahmed OI, El-Hady SA, Ahmed TM, Ahmed IZ (2013) Detection of bla SHV and bla CTX-M genes in ESBL producing Klebsiella pneumoniae isolated from Egyptian patients with suspected nosocomial infections. Egyptian Journal of Medical Human Genetics 14(3):277-83.

Al Sanjee S, Haque A, Banerjee S, Hoque MS, Moniruzzaman M, Das KC, Karim ME (2020) ESBL producing Escherichia coli and Klebsiella pneumoniae from burn wound infection. International Journal of Biosciences 16(5):145-155.

Aljanaby AAJ (2013) Antibacterial activity of an aqueous extract of Petroselinum crispum leaves against pathogenic bacteria isolated from patients with burns infections in Al-Najaf Governorate, Iraq. Research on Chemical Intermediates 39: 3709.

Aljanaby AAJ (2018) Antibacterial activity of an aqueous extracts of Alkanna tinctoria roots against drug resistant aerobic pathogenic bacteria isolated from patients with burns infections. Russian Open Medical Journal 7: 1-6.

Aljanaby AAJ, Alhasani AH (2015) Prevalence of blaTEM and blaSHV genes in multidrug resistant Klebsiella pneumoniae isolated from hospital patients with burns infections in Al-Najaf governorate-Iraq. World Journal of Pharmaceutical Research 4(7):145-54.

Aljanaby AAJ, Alhasnawi HM (2017a) Phenotypic and molecular characterization of multidrug resistant Klebsiella pneumoniae isolated from different clinical sources in Al-Najaf Province-Iraq. Pakistan Journal of Biological Sciences 20(5):217-32.

Aljanaby AAJ, Medhat AR (2017b) Prevalence of Some Antimicrobials Resistance Associated-genes in Salmonella typhi Isolated from Patients Infected with Typhoid Fever. Journal of Biological Science 17 (4): 171-184.

Aljanaby AAJ, Tuwaij NSS, Al-khilkhali HJB (2018) Antimicrobial susceptibility patterns of Klebsiella pneumoniae isolated from older smokers and non-smokers of inpatients in intensive care unit infected with chronic pneumonia in AL-Najaf hospital, Iraq. Journal of Pharmaceutical Sciences and Research 10(5): 1093-1097.

Amirkamali S, Naserpour-Farivar T, Azarhoosh K, Peymani A (2017) Distribution of the bla OXA, bla VEB-1, and bla GES-1 genes and resistance patterns of ESBL-producing Pseudomonas aeruginosa isolated from hospitals in Tehran and Qazvin, Iran. Revista da Sociedade Brasileira de Medicina Tropical 50(3):315-20.
Barguigua A, El Otmani F, Talmi M, Bourjilat F, Haouzane F, Zerouali K, Timinouni M (2011) Characterization of extendedspectrum $\beta$-lactamase-producing Escherichia coli and Klebsiella pneumoniae isolates from the community in Morocco. Journal of Medical Microbiology 60(9):1344-52.

Bauer AW, Kirby WM, Sherris JC, Turck M (1966) Antibiotic susceptibility testing by standard single disc method. American Journal of Clinical Pathology 45:493-6.

Bengtsson-Palme J, Kristiansson E, Larsson DJ (2018) Environmental factors influencing the development and spread of antibiotic resistance. FEMS Microbiology Reviews 42(1):fux053.

Borges A, Abreu AC, Dias C, Saavedra MJ, Borges F, Simões M (2016) New perspectives on the use of phytochemicals as an emergent strategy to control bacterial infections including biofilms. Molecules 21(7):877.

Clinical and Laboratory Standards Institute (CLSI) (2020) Performance Standards for Antimicrobial Suscep-tibility Testing; $30^{\text {th }}$ ed. Informational Supplement. PA, USA.

Derakhshan S, Peerayeh SN, Bakhshi B (2016) Genotyping and characterization of CTX-M-15-producing Klebsiella pneumoniae isolated from an Iranian hospital. Antimicrobial Agents and Chemotherapy Journal 28(4):289-96.

El-Mokhtar MA, Daef E, Mohamed Hussein AA, Hashem MK, Hassan HM (2021) Emergence of Nosocomial Pneumonia Caused by Colistin-Resistant Escherichia coli in Patients Admitted to Chest Intensive Care Unit. Antibiotics 10(3):226.

Ensor VM, Jamal W, Rotimi VO, Evans JT, Hawkey PM (2009) Predominance of CTX-M-15 extended spectrum $\beta$-lactamases in diverse Escherichia coli and Klebsiella pneumoniae from hospital and community patients in Kuwait. International Journal of Antimicrobial Agents 33(5):487-9.

Gupta V, Kumarasamy K, Gulati N, Garg R, Krishnan P, Chander $\mathrm{J}$ (2012) AmpC $\beta$-lactamases in nosocomial isolates of Klebsiella pneumoniae from India. Indian Journal of Medical Research 136(2):237.

Hansen JK, Voss J, Ganatra H, Langner T, Chalise P, Stokes S, Bhavsar D, Kovac AL (2019) Sedation and analgesia during pediatric burn dressing change: a survey of American Burn Association centers. Journal of Burn care \& Research 40(3):28793.

Hernando-Amado S, Coque TM, Baquero F, Martínez JL (2019) Defining and combating antibiotic resistance from One Health and Global Health perspectives. Nature Microbiology 4(9):1432-42. 
Izadi N, Naderi Nasab M, Harifi Mood E, Meshkat Z (2014) Prevalence of TEM and SHV Genes in Clinical Isolates of Klebsiella Pneumonia From Mashhad, North-East Iran. Iranian Journal of Pathology 9(3):199-205.

Jeschke MG, van Baar ME, Choudhry MA, Chung KK, Gibran NS, Logsetty S (2020) Burn injury. Nature Reviews Disease Primers 6(1):1-25.

Kandela NJ (2011) Detection of Extended Spectrum BetaLactamase (ES $\beta \mathrm{L})$ and Klebocin Production from Klebsiella pneumoniae Local Isolates from Urinary Tract Infections. AlMustansiriyah Journal of Pharmaceutical Sciences 9(1):21-42.

Kaur J, Chopra S, Sheevani GM (2013) Modified double disc synergy test to detect ESBL production in urinary isolates of Escherichia coli and Klebsiella pneumoniae. Journal of Clinical and Diagnostic Research 7(2):229.

King DT, Sobhanifar S, Strynadka NC (2016) One ring to rule them all: Current trends in combating bacterial resistance to the $\beta$-lactams. Protein Science 25(4):787-803.

Landecker H (2016) Antibiotic resistance and the biology of history. Body \& Society 22(4):19-52.

Lari AR, Azimi L, Rahbar M, Fallah F, Alaghehbandan R (2013) Phenotypic detection of Klebsiella pneumoniae carbapenemase among burns patients: first report from Iran. Burns 39(1):174-6.

Leber AL (2020) Clinical microbiology procedures handbook John Wiley \& Sons.

Legese MH, Weldearegay GM, Asrat D (2017) Extended-spectrum beta-lactamase-and carbapenemase-producing Enterobacteriaceae among Ethiopian children. Infection and Drug Resistance10:27.

Lewies A, Du Plessis LH, Wentzel JF (2019) Antimicrobial peptides: the Achilles' heel of antibiotic resistance? Probiotics and Antimicrobial Proteins 11(2):370-81.

MacFaddin JF (2000) Biochemical Tests for Identification of Medical Bacteria. Williams and Wilkins publication Philadelphia, PA. Pp.113.

Majeed HT, Aljanaby AAJ (2019) Antibiotic susceptibility patterns and prevalence of some extended spectrum betalactamases genes in gram-negative bacteria isolated from patients infected with urinary tract infections in Al-Najaf City, Iraq Avicenna Journal of Medical Biotechnology 11(2):192.

Mariya S, Hatkar SS (2015) Antimicrobial susceptibility profile of urinary isolates of Escherichia coli and Klebsiella pneumoniae. International Journal of Health Sciences and Research 5(2):169-72.
Miryala SK, Anbarasu A, Ramaiah S (2020) Role of SHV-11, a class a $\beta$-lactamase, gene in multidrug resistance among Klebsiella pneumoniae strains and understanding its mechanism by gene network analysis. Microbial Drug Resistance 26(8):900-908.

Navon-Venezia S, Kondratyeva K, Carattoli A (2017) Klebsiella pneumoniae: a major worldwide source and shuttle for antibiotic resistance. FEMS Microbiology Reviews 41(3):252-75.

Neog N, Phukan U, Puzari M, Sharma M, Chetia P (2021) Klebsiella oxytoca and Emerging Nosocomial Infections. Current Microbiology 3:1-9.

Paterson DL, Hujer KM, Hujer AM, Yeiser B, Bonomo MD, Rice LB, Bonomo RA (2003) International Klebsiella Study Group. Extended-spectrum $\beta$-lactamases in Klebsiella pneumoniae bloodstream isolates from seven countries: dominance and widespread prevalence of SHV-and CTX-M-type $\beta$-lactamases. Antimicrobial Agents and Chemotherapy 47(11):3554-60.

Rup AR, Dash AK, Patnaik S (2021) Ceftazidime-Avibactam for Hospital Acquired Pneumonia Due to Extended Drug-Resistant Klebsiella pneumoniae. Indian Journal of Pediatrics 88(3):290-1.

Salih RM, Mustafa KK, Abdulrahman ZF (2018) Anti-biotypes of Different Bacteria Isolated from Different Clinical Sources. Tikrit Journal of Pure Science 21(1):21-30.

Sharahi JY, Ahovan ZA, Maleki DT, Rad ZR, Rad ZR, Goudarzi M, Shariati A, Bostanghadiri N, Abbasi E, Hashemi A (2020) In vitro antibacterial activity of curcumin-meropenem combination against extensively drug-resistant (XDR) bacteria isolated from burn wound infections. Avicenna Journal of Phytomedicine 10(1):3.

Soucy SM, Huang J, Gogarten JP (2015) Horizontal gene transfer: building the web of life. Nature Reviews Genetics.6(8):472-82.

Sugumar M, Kumar KM, Manoharan A, Anbarasu A, Ramaiah S (2014) Detection of OXA-1 $\beta$-lactamase gene of Klebsiellapneumoniae from blood stream infections (BSI) by conventional PCR and in-silico analysis to understand the mechanism of OXA mediated resistance. PLoSOne 9(3):e91800.

Tang Y, Shen P, Liang W, Jin J, Jiang X (2017) A putative multireplicon plasmid co-harboring beta-lactamase genes bla KPC-2, bla CTX-M-14 and bla TEM-1 and trimethoprim resistance gene dfrA25 from a Klebsiella pneumoniae sequence type (ST) 11 strain in China. PloS one 12(2):e0171339.

Tong W, Yang M, Wang H, Feng X, Zhang L, Zhou B, Chen F, Huang F, Chen X, Cai Y, Yu L (2021) Effects of different tillage methods on bacterial community and enzyme activity of 
rhizosphere of flue-cured tobacco in Yunnan mountains. International Journal of Agriculture and Biology 25(2):345-53.

Tuwaij NS, Aziz ZS, Al-ghazaly NF (2020) Investigation of genes associated with producing beta-lactamase among Burkholderiacepacia isolates. EurAsian Journal of BioSciences 14(1):1919-24.

Yap PSX, Lim SHE, Hu CP, Yiap BC (2013) Combination of essential oils and antibiotics reduce antibiotic resistance in plasmid-conferred multidrug resistant bacteria. Phytomedicine 20(8-9):710-3.
Yezli S, Shibl AM, Memish ZA (2015) The molecular basis of $\beta$ lactamase production in Gram-negative bacteria from Saudi Arabia. Journal of Medical Microbiology 64(2):127-36.

Zowawi HM, Sartor AL, Balkhy HH, Walsh TR, Al Johani SM, AlJindan RY, Alfaresi M, Ibrahim E, Al-Jardani A, Al-Abri S, Al Salman J (2014) Molecular characterization of carbapenemaseproducing Escherichia coli and Klebsiella pneumoniae in the countries of the Gulf cooperation council: dominance of OXA-48 and NDM producers. Antimicrobial Agents and Chemotherapy 58(6):3085. 